DEMOCRATIC ACCOUNTABILITY 

Leif Lewin

\section{Democratic Accountability}

Why Choice in Politics Is Both

Possible and Necessary 
Copyright $\odot 2007$ by the President and Fellows of Harvard College All rights reserved

Printed in the United States of America

ISBN-13: 978-0-674-02475-5

ISBN-10: 0-674-02475-3

The Cataloging-in-Publication Data is available from the Library of Congress. 